SHS Web of Conferences 12, 01102 (2014)

DOI: $10.1051 /$ shsconf/20141201102

(C) Owned by the authors, published by EDP Sciences, 2014

\title{
Tourism Development Plan for Nova Lima, MG/BR: A Case Study
}

\author{
Aluisio Finazzi Porto ${ }^{1}$, Marcos Eduardo C.G. Knupp ${ }^{2}$, Paulo de Tarso Phenee ${ }^{3}$ \\ ${ }^{1,2}$ Tourism Department, Federal University of Ouro Preto, 35400-000 Campus Morro do Cruzeiro, \\ Ouro Preto, Brazil \\ ${ }^{3}$ Tie Incentivos Ltda, Maestro Elias Lobo 1040 cj 64, São Paulo, Brazil
}

\begin{abstract}
The project called "Tourism Development Plan of Nova Lima, MG" was a labor required by the city of Nova Lima, through the Secretary of Municipal Tourism. The municipality of Nova Lima has numerous tourist attractions or potential for them attractive, and is developing a work of public policies aimed at structuring this activity. The objective of this project was to offer to its population, as well as the government and the private sector, the assurance of quality activity according to the international, national and state the assumptions referred to in the Municipal Tourism Plan. All work was developed by Scientific and Technical Research Data Collection, which took into consideration the participation of local stakeholders in the development of tourism through public hearings with the Section for Local Tourism, making use of Information from the Current Municipal Development Plan for Nova Lima and its Secretary of Tourism. We also note that the study was conducted in accordance with the guidelines and considerations of the Municipal Tourism Council (COMTUR) of Nova Lima.
\end{abstract}

\section{Introduction}

The project called "Tourism Development Plan for Nova Lima, MG" was a labor required by the city of Nova Lima, through the Secretary of Municipal Tourism. The municipality of Nova Lima has numerous tourist attractions or potential for them attractive, and is developing a work of public policies aimed at structuring this activity. Public policies need to be implemented and that there are measures and instruments, ranging from deciding who has the power to convince the social actors. The implementation is a negotiation process that includes the intention of the government policies, and the tension and negotiation with stakeholders [1].

However, the need arose to review management tools so that there was continuity to the work that has been developed over the last decade. Therefore, the present study aimed to contribute to the municipality of Nova Lima it making opportunities toward a mechanism of paramount importance to the strategic management of tourism. The goal was to offer to its population, as well as the government and the private sector, the assurance of quality activity according to the international, national and state the assumptions referred to in the Municipal Tourism Plan. [2] define tourism policy as a set of regulations, rules, guidelines, policies, objectives and strategies of development and promotion that provides a framework in which collective and individual decisions directly affecting tourism development and daily activities are taken within a destination.

Therefore, the review process of the Plan Works Tourism Development, Review of Marketing Plan, Technical Training and Support for Entrepreneurship are of paramount importance for the 
municipality to develop tourism and raise the necessary resources at the Ministry of Tourism to leverage tourism in the region.

The Brazilian government over the last decade, has been consolidating tourism nationwide, not only by hosting important sports mega events to capture tourists and foreign investment, but also by understanding that tourism can bring currency and work for Brazilian municipalities. In this way, the federal government has been providing increased resources to municipalities to develop tourism in a planned and sustainable manner. So that the government, through the Ministry of Tourism, can make use of its resources, all municipalities must conform to ordinance 112 MTUR launched on March 9, 2012 in the Official Gazette [3].

It is recognized that since Nova Lima presents part of the necessary requirements to comply with this ordinance, as the acting Municipal Council of Tourism, the active Municipal Tourism Fund assets, the Tourism Interest Inventory, and the Municipal Tourism Plan, all are based on the policy for Tourism in Nova Lima, and are indicative of the solution for Works and Marketing.

\section{Facts about Municipality}

\subsection{Location and accessibility}

Nova Lima is located in the Metropolitan Region of Belo Horizonte in Minas Gerais State. It is a city recognized for its importance in minerals, and many mines are in the city, whose extracted minerals include gold. Currently, it is known as well for the active development of tourism, specifically ecotourism and adventure tourism. Its estimated population in 2010 was 81,162 inhabitants [4].

The border of Nova Lima and Belo Horizonte is formed by the south-central area of the capital which has attracted residents of high income for this area, settling in high-end luxury condos in the city. In 2010, Nova Lima revealed that it is the leading city in Minas Gerais for quality of life, according to PNUD Ranking [5].

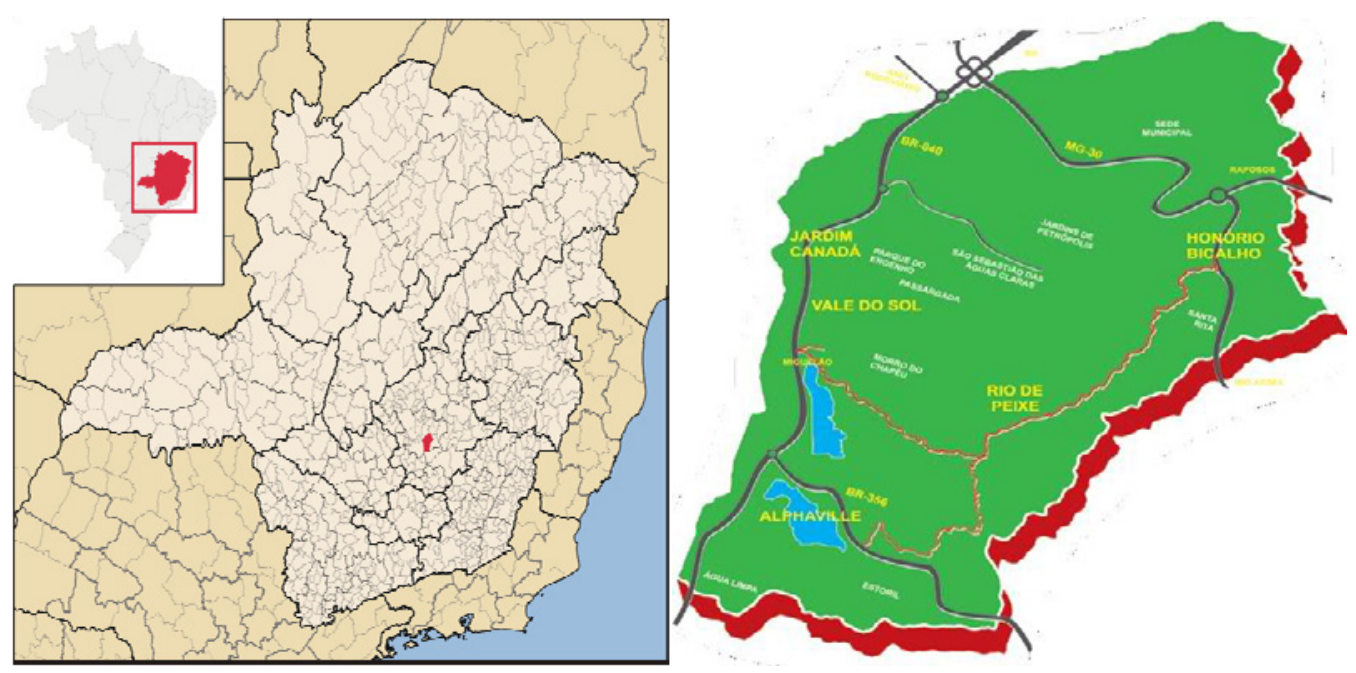

Figure 1. Location and districts of the municipality of Nova Lima

The neighboring municipalities of Nova Lima are: Belo Horizonte and Sabara, to the north; Itabirito, to the south; Raposos to the east; Brumadinho to the west; and Rio Acima, to the southeast. The city has six districts in addition to its centers that are the towns of Honorius Bicalho, Santa Rita, the Rio do Peixe and São Sebastião das Águas Claras (Macacos) and Canada Garden. 


\subsection{Hidrografic Network}

The hydrographic network includes several rivers and streams that supply the reservoirs of the capital, making it relevant for the preservation of the watersheds. Those that stand out are: Velhas River, Crystal Creek, and Ribeirão Cardoso. Its topography consists of mountains and hills that are part of the Serra do Espinhaço, preserved through the Conservation Units (CUs), highlighting the Serra da Moeda and Serra da Calçada, which frame the municipality.

\subsection{Historical Dimension}

At the end of the seventeenth century, the Minas Gerais region was explored by several groups that ventured into the territory in search of gold and precious stones. With the news of discovered riches, the first miners grew rapidly in numbers. They were freed men, slaves, adventurers, whose names were not kept in history. The discovery of gold veins occurred frequently, which occasioned an active trade and high occurrence of herders, and thus other miners came to explore, searching for metal in the rivers of Bela Fama, Cachaça da Gaia, Faria Garcês, and Urubu, among others.

Already in 1726, mines were being granted to twelve government representative explorers. Also in that year, several mills were established alongside the various granted mineral enterprises, making the place a haven for gold in colonial times (IBGE, 2008). The encampment that formed there gained a church, elevated in 1748 to the level of a parish.

However, the town developed with more order when the Morro Velho Mine began to be worked by the Saint John D'El Rey Mining Company Limited. The presence of British culture in the region is explained precisely by the purchase of the Morro Velho Mine by Saint John del Rey Mining Company in 1834. With the end of the gold cycle, economic activity became predominantly maintaining a livelihood. And in 1836 the district was created, under the authority of the city of Sabara, with the name of Congonhas Sabara.

The date of February 5, 1891 marks the emancipation of the municipality, which finally elevated from encampment to village, freed from being subordinate to Sabara, then called Villa

Nova Lima, after the illustrious Antonio Augusto de Lima, historian, poet and politician, illustrious son of the soil and a member of the Brazilian Academy of Letters and the Brazilian Historic and Geographic Institute, and who governed the state at the dawn of the Republic. Only in 1923 did Nova Lima receive its name that remains to this day [3]. Therefore, the place name is currently Nova Lima (New Limense).

\section{Methodology}

This report was built upon completion of the project, "Tourism Development Plan for Nova Lima, MG," developed by the company Tié Incentives and its team of collaborators including researchers and professionals specialized in public management. It aims to upgrade and increase Tourism Planning in the municipality of Nova Lima, MG. The actions were based on the elaboration of the major points in relation to the Plan for Elements of Tourism Development, revising Tourism Marketing of the municipality, form the Plan for the Support for Entrepreneurship and Technical Training for the local tourist trade.

All work was developed by Scientific and Technical Research Data Collection, which took into consideration the participation of local stakeholders in the development of tourism through public hearings with the Section for Local Tourism, making use of Information from the Current Municipal Development Plan for Nova Lima and its Secretary of Tourism. We also note that the study was conducted in accordance with the guidelines and considerations of the Municipal Tourism Council (COMTUR) of Nova Lima.

Initially, the municipality collected secondary data through official documents of the municipality, such as laws, Plans, Minutes, research reports, programs and projects of interest or others containing tourism-related activities of the municipality. These data were properly analyzed culminating in a 
diagnosis that preserved the studies and proposals for tourism planning in Nova Lima. This provided a broad overview of their current context, thus giving consistency and continuity to the development of the tourist activity that is happening in the city.

Subsequently, through techniques of quantitative and qualitative research, which enabled us to merge two types of searches that frame the construction of the proposed methodological scheme, semi-structured questionnaires were administered and interviews were conducted with the three main audiences of research: tourist trade, local population and members of COMTUR. This consideration was essential for the work to be completed successfully, since these collected data and information provided the analysis of tourism based on different perspectives.

In order to follow a schematic assessment framework and construction of the proposed work, 5 steps were performed to culminate in activities to implement this project.

To perform the first step, according to the Plan of Work, site visits were made in order to assess the main points of interest for development works in the city to encourage the development of tourism.

The second step, in turn, refers to this Tourism Inventory of the municipality in which an analysis of the trade and the attractions of the region, resulting in proposals for the consolidation of Nova Lima as a national and international tourist destination was performed.

The third step was the proposal of marketing, specifically in relation to a dissemination plan. This is considered a key point, given that by structuring the county to receive the tourist attractions prepare and plan the schedule of annual events, it becomes essential to properly disclose final aims in order to capture the right audience for the tourist attractions.

Finally, the fourth and fifth stages correspond to the plan for Entrepreneurship and Technical Training. For these steps, a tool was developed, the Technical Manual, which greatly assists the municipality in promoting and directing the trade and workers of the area with respect to existing governmental actions. The Construction Manual is an important step toward the development of the sector, bringing professionalization as the flagship activity.

\section{Tourism in Nova Lima}

\subsection{Infrastructure}

The first action of the project was the inventory of Tourism and Trade in Nova Lima. Possibly, improving the Inventory of Tourist Offerings, including maps would be an option that would trigger more accurate analyses for the formulation of land use planning and tourism analysis, as well as providing a mechanism for assistance to tourists, facilitating their movement through the region and their visits to natural attractions. The first action was a data research, with this tourism inventory. After, it was done a reserch with the tourists and local people. The results are the basis for the analisis and conclusions about the fields where tourism can grow in Nova Lima. The spread of commercial tourist centers shows how the support services for tourism are organized and shared in the municipality. It is clear that most of these establishments are in the municipal center, demonstrating that few establishments of this type of activity are elsewhere in the city. Even in spots that receive a considerable number of visitors, such as Macacos, there are not a large number of Bars, restaurants, pizzarias and steak houses in the municipality. We understand that this type of business is well distributed among the major regions receiving a large influx of visitors, such as Macacos, the Municipal Center and Route 040. However, there is great disparity between the distribution of means of lodging in the municipality where the vast majority are located in Macacos. In the municipal center there are only two hotels, demonstrating a great slack with regard to the question of lodging in the center of the city. We believe this merger happens because Macacos is actually the tourist hub of the region, while other regions do not yet receive a large influx of tourists. Others either receive a stream of visitors, but as passers-by, such as along Route 040, which receives people from Belo Horizonte during the daytime due to the natural attractions that are located there. The visitors practice nature tourism and ecotourism, and return to their starting point, but without making use of lodging. 
Moreover, the limited number of establishments with lodging facilities in the center of town does not allow tourists to stay to enjoy the events that happen at night. I.e., this makes participation difficult for the large influx of tourists taking part in the events that happen or will happen in the center of town at night. They have to leave and go to other districts, such as Macacos, or even other neighboring cities such as Belo Horizonte, for example, to spend the night.

\subsection{Tourist attractions}

Regarding Tourist Attractions, there is a balance between the supply of cultural attractions and events, while there is a lower supply of natural attractions. However, we must look at the potential of the latter, since the region is full of natural beauty and conservation units and some are heavily used by visitors, while others are not yet. Therefore, the development of actions that focus on this potential would greatly add to the visitor experience in the region and the illustrated maps can assist in this process, demonstrating the potential to develop more equipment such as theme parks, eco trails, atracting entrepreneurs who can develop more recreational options, such as welcoming tourist areas aimed at eco-tourism, for example. The development of projects on local tourism through cultural, educational and sporting activities in order to set sustainable development of tourism is of paramount importance to tourist destinations. These actions would be aimed at the conservation of historic and artistic values of Nova Lima, with a view to developing a cultural preservationist frame of mind and the encouragement of cultural practices to identify, recognize and preserve the cultural and natural heritage. Currently, the debate surrounding the preservation of cultural memory and the democratization of knowledge and historical spaces, as well as the appropriation of history and culture permeates the issue of sustainability and a required involvement of society. The community itself, realizing the importance of preservation, can raise the visibility of its cultural roots and production and beauties of nature, contributing to the experience of its visitors. Thus, schooling for tourism through programs of heritage education are extraordinary necessary for the municipality of Nova Lima.

\subsection{Events}

The importance of holding events for tourist destinations is essential for the development of tourism. The events help the cities in overcoming seasonality, spreading the flow of tourists throughout all the months of the year in order to bring resources to the location, its companies and the people involved in the activity. Figure 2 shows the spreading of events in Nova Lima according to the months of the year. Not all of these events have the potential or appeal for tourism, nor are they likely to draw a stream of tourists and visitors. Many of the events are geared towards the local community, such as religious festivals and local sporting events. However, others have a strong tourist appeal and have the potential to attract not both national and also international tourists, as is the case of Octoberfest, for example.

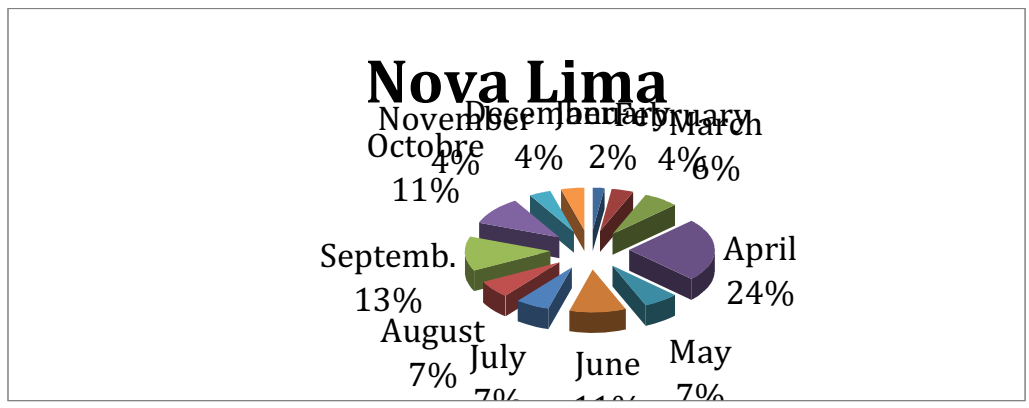

Figure 2. Popular and Folklore Festivals, City, Environmental and Sports Celebrations 
We can see that the spreading of events in Nova Lima is divided among all months of the year, with a concentration in April, a month that has many religious events, along with the months of June, September and October. The analysis that we can make of this dispersal is that Nova Lima, being close to a capital city with a population eager to leave its place of residence and partake of leisure activities in other localities, is strategically located with a great potential to carry out events, which would at least attract the public from Belo Horizonte and other national and international visitors making use of the airline hub of the capital.

Events such as those for End of the Year, the anniversary of the city, the Ecological Parade, the Farmers' Festival and others can be great opportunities for this.

\section{Procedure for planning and strategies}

\subsection{LPA's (Local Productive Arrangements) of rustic furniture and micro breweries}

The region of Canada Garden, near the highway BR-380, offers several companies targeting landscaping and construction, and rustic furniture made with recycled wood. However, only residents of the region of Belo Horizonte know this trade, which is typical of Minas Gerais, since there are many old buildings that undergo renovations, providing a vast amount of raw material. Further, the ties from railroad tracks are widely used in building rustic furniture, increasing the recyclability of materials.

Today there is local development, of support for the development of Local Productive Arrangements, called LPA's. The creation of a Development Plan for Industry in Rustic Furniture, will greatly help entrepreneurs in the region, generating jobs and income, and a highly sustainable tourism.

Another sector that must be provided with an LPA is microbreweries. Nova Lima has more than twenty (20) breweries, that even participate in October Fest, a local festival of bier called. Already the consensus is that the city is a genuine seat for breweires because of the quality of its water and the European tradition, due to the British colonization of the region. An APL may invigorate the production, dissemination and marketing of the product both regionally and nationally and internationally, since there is a great exchange between local and foreign brewers.

\subsection{Law of visual pollution}

The challenge of public managers for Nova Lima is the revitalization of the central region of the County Seat. There is a great amount of visual pollution, both in relation to commercial signage, which is placed over the existing architectural profile of the facades of houses and townhouses, in both public spaces and facilities, such as bus stops, exposed electrical wires and poles and in inappropriate places, banner ads and inadequate lighting.

To regulate the size of the billboards in the city, and to reorganize the use of public facilities is extremely important to the city. To reorder traffic in the central region, mainly around the central square and the garden square of Vila Nova depends upon legislative actions, given the need for adoption of regulations against visual pollution. Encourage maintenance and painting of houses and townhouses through the property tax abatement, may be a good strategy to be adopted.

\subsection{Train station}

Honorio Bicalho was the starting point for the city of Ouro Preto. The Railroad connecting Nova Lima to the goldmines was built by the British, who brought bricks and the iron that would build the structure, through the Rio das Velhas, which divides the district of Honorio Bicalho. At that point, the train station was erected, where groceries went out and gold came back between the two municipalities. After the demise of the railroad, it was dropped completely, today leaving only the foundations next to the train tracks. 
With the possibility of reactivation of the railroad between Honorio Bicalho and the city of Rio Acima, there must be created, in the short term, an architectural and urban design for the district in order to encourage the revitalization of the district through tourism. To encourage the APL of breweries also to develop that area can also be a great generator of employment and income for residents, by installing breweries that sell their products near the station, thus attracting tourists. In order to ensure a more complete travel experience, in the actual central square of the district, the construction of a CAT or even a Totem with information about the Eco Paths of the district and its natural beauties would add greatly to the visiting tourists.

\subsection{Conservation units}

Conservation Units can be the gateway to the development of an environmentally friendly and economically sustainable tourism. Thus, we propose the following actions perspective to eco-tourism and adventure.

Systematic monitoring of tourism in the Natural Monument of Serra da Calçada and São Sebastião das Águas Claras; Development of a Management Plan for the Natural Monument of Serra da Calçada providing capacity for tourism and public use; Development of Management Plans of protected areas; Specific proposals for the region of Macacos and the Natural Monument of Serra da Calçada; Creation of effective environmental education campaigns for the community directly involved with the focuses of local tourism; Support the implementation of the Public Use Plan of the Serra do Rola Moça, published in 2007 by IEF.

\subsection{Entrepreneurship and technical training}

The present work produced a Manual for the Entrepreneur which aims to provide a guide to local business owners on how to benefit from the resources offered by public institutions to make their company increasingly more competitive in local, national and international tourist markets.

In this sense, we present in this guide step-by-step directions for registering companies with the CADASTUR, program of the Ministry of Tourism, key item to facilitate obtaining resources and funding in order to make them more visible and competitive in the tourism market. Subsequently, we highlight the PRONATEC, a program of courses for professional improvement for entrepreneurs to empower and encourage their colleagues in order to offer products and services of excellence and quality.

Finally, we show the major public funding for tourism in Brazil. First, we present the financing of the Bank of Brazil and BNDES, which have increasingly shown interest in encouraging the growth of the sector, facilitating the private sector and boosting tourism in Brazil to be competitive in the fierce national and international market.

\section{Conclusion}

The conclusion of this labor is that with planning and sistems of control, principally with the participation of Nova Lima's population, the development of tourism can be projected and budget. A study by [6] emphasizes the role of permanent negotiation in the implementation of public policies . According to the authors, the policy-making is a social process that involves constant communication with the various spheres in which decisions are taken, not only in public level, but also within a society characterized by fragmentation, since as noted in the analysis of the tourism phenomenon, this covers multiple sectors, stakeholders as well as not interested. We also note that the study was conducted in accordance with the guidelines and considerations of the Municipal Tourism Council (COMTUR) of Nova Lima. This is an important guide for so many other cities in Brazil and other coutries that needs to do this job immediatly. 


\section{References}

1. O. Krutwayshok, and B. Bramwell, Tourism policy implementation and society, Annal of Tourism Research ,3, 670-691 (2010)

2. C. Goeldner, B. Ritchie J.R. and R. McIntosh, Tourism: Principles, Practices, Philosophies, Porto Alegre, Bookman, (2002)

3. http://www.turismo.gov.br/turismo/legislacao/portarias/20130903-1.html

4. Instituto Brasileiro de Geografia e Estatística, Census, (2010)

5. United Nations Development Programme, Atlas of Brasil Development, (2010)

6. N. Stevenson, D. Ayrey, G. Miller, Tourism policy making: The policymaker's perspective, Annals of Tourism Research, 35, 33, 732-750 (2008) 